Chapter 3:

Performing Power and Identity 



\title{
Singing in the Blend: Stagings of Verdi's Operatic Shakespeare in the Czech Republic after 1989
}

Šárka Havlíčková Kysová

\begin{abstract}
The article deals with changes in creating scenography for productions of operas based on plays by William Shakespeare in former Czechoslovakia and the Czech Republic after 1989. The article discusses the procedure of a multimodal analysis of scenography based on blending theory approach. The 1991 production of Verdi's Otello of the Prague State Opera directed by Dominik Neuner and revived in 2009 by Lubor Cukr is used as an example of creating scenographic space for operatic Shakespeare. The scenography is understood as not only visual but multimodal component of theatrical performance. Vladimír Nývlt's concept of scenography for the Otello production is treated from the perspectives of multimodal analysis and examined in the context of other productions of operatic Shakespeare in the Czech Republic after 1989.
\end{abstract}

\section{Key words}

opera, theatre, Giuseppe Verdi, Arrigo Boito, Otello, Prague State Opera, National Theatre Prague, Dominik Neuner, Lubor Cukr, Vladimír Nývlt, conceptual metaphor, conceptual blending, multimodal metaphor 
In former Czechoslovakia during the Communist regime, Giuseppe Verdi's Otello was a consistent part of the repertory of opera theatres. Otello had been staged in Czechoslovak theatres since the beginning of its staging history. ${ }^{1}$ In contrast, Verdi's Macbeth ${ }^{2}$ had not become an established work in the repertory of Czechoslovak theatres, ${ }^{3}$ with the work not staged at all until $1975 .{ }^{4}$ Verdi's operatic Otello was usually presented scenographically as a 'tragic' story from the Elizabethan era. Creating an Elizabethan-type scenography with many expressive elements was 'safe,' or, rather, 'not risky' during the Communist era, since the sujet could be projected 'neutrally' as 'history', avoiding all possible reference to the Communist regime. With the loosening of censorship, especially during the 1980s, a part of a period known as Normalisation in Czechoslovakia, a more metaphorical approach, including more abstract, non-descriptive means of expression especially in scenography, started to be used, but still rather cautiously not to provoke the Communists. ${ }^{5}$ After the Velvet Revolution in 1989, the theatrical means of expression used in operatic productions, including Shakespearean operas, underwent a number of substantial changes, overall moving towards a more figurative approach to staging.

In the present article I focus on the post-1989 productions of three National Theatres (NT) in the Czech Republic: the National Theatre in Prague, National Theatre in Brno, and National Theatre in Ostrava. I mainly analyse the details of the Prague production of Otello (1991, remounted in 2009) from the point of view of multimodal metaphor theory, which facilitates an understanding of the complexity of meaning by examining the process of its construction. I compare the Prague production's staging style with the findings of my former research focused on the staging of operatic Shakespeare. I support my arguments with findings about the production of Macbeth (NT Prague 2015) and Macbeth (NT Ostrava 2004). I deal with the shift between the staging traditions of Macbeth and Otello before and after $1989 .{ }^{6}$ My primary angle is scenography and the directing-scenographic conception of the productions.

1 Otello premiered in Teatro alla Scala on 5 February 1887. The very first production of the opera in Prague premiered less than one year later (7 January 1888).

2 The opera premiered in 1847 in Florence and its second, the so-called 'French', revised version premiered in 1865 in Paris.

3 Verdi's comic Shakespearean opera Falstaff was popular with the spectators and at the same time was good enough to be tolerated by the official culture politics.

4 According to the archival materials and repertory records, the very first production of Macbeth in Czechoslovakia was in the Silesian Theatre in Opava in 1975. Jitka Ludvová, Czech scholar who focuses in her research on the history of German (musical) theatre on Czech lands, confirms this information. Even the very first production of Macbeth in the Prague German Theatre was performed not earlier than in 1935. (Private correspondence with Ludvová from 10 July 2019).

5 For more information on the historical context of theatre and productions of Shakespeare's plays please refer to MIŠTEROVÁ's article in this collection.

$6 \quad$ I also refer to my analyses of several Czech productions of Verdi's Otello (Prague, 1965; Brno, 1967; Brno, 1989) and Macbeth (Prague, 1978; Brno, 1987), including the productions after 1989 (Ostrava, 2004; Brno, 2009; Prague, 2015) (see HAVLÍČKOVÁ KYSOVÁ forthcoming 2021). For a detailed analysis of Otello as staged in Brno in 1967, please refer to (HAVLÍČKOVÁ KYSOVÁ 2016). 


\section{Scenography as a blend: methodological considerations}

Scenography is an intricate notion in theatre studies. In former Czechoslovakia, especially in the $1960 \mathrm{~s}$, it came to refer to not only an artistic discipline, but also to a scientific discipline, and a part of theatre studies. It started to be understood as a complex discipline creating an original, often highly interpretative part of the staging. Scenography was often contrasted to stage design with its 'simpler' task of designing the stage for a particular play or opera. ${ }^{7}$ This concept of scenography was mostly based in the structuralist approach to theatre developed since the interwar period by the Prague School.

Scenography has played a crucial part in theatre productions, including the staging of opera. During the $20^{\text {th }}$ century approaches to stage design and scenography changed significantly worldwide. Czech theatre practitioners and theorists also supported shifts in the scenographic component of performance. In this context, I treat (operatic) scenography as a complex, multimodal discipline, which includes not only visual aspects, but other modes of expression, especially the audial. Scenography also constitutes an integral part of direction.

To understand how scenography works I use approaches from cognitive studies. From this perspective, scenography can be understood as one multimodal component within theatrical production, itself a multimodal discourse. In terms of multimodality as developed by Charles Forceville (2009), especially in opera, more than the visual element (mode) is involved in scenography. Forceville describes several modes of communication: pictorial signs, written signs, spoken signs, gestures, sounds, music, smells, tastes, and touches (FORCEVILLE 2009: 21). In the former Czechoslovakia, the concept of scenography as a complex discipline was developed in the work of theatre practitioners, most of all František Tröster and Josef Svoboda. As such a complex discipline, it was reflected and formulated by the Czech theatre studies scholar and structuralist theorist of scenography Vladimír Jindra (1983), who anticipated in a number of ways a multimodal approach to scenography. In Jindra's approach, scenography communicates not only through its visual mode ('component' in Jindra's words), but also through other modes such as sound and music, etc. (JINDRA 1983: 72-73). In Jindra's understanding, even the visual mode of scenography is complex and cannot be reduced simply to a 'visual aspect' (JINDRA 1983: 93), i.e., it includes various other modes ('immaterial subcomponents') such as light or colour (JINDRA 1983: 72-73). Jindra's notion that these components penetrate all the levels and components of theatrical art anticipates to some extent the analytical and creative processes within the field of multimodality. To analyse an art as complex as scenography, in this article I use a three-step or, more precisely, three-layered analysis to interpret scenographic elements of production.

$7 \quad$ The shift in approach to designing the stage and its theoretical perspective also reflects various historical practices of scenic design. The making of the stage for a performance changed substantially in the $19^{\text {th }}$ and at the outset of the $20^{\text {th }}$ century. For example, Vladimír Jindra (1983) distinguishes and defines four fundamental stages of development of approaches toward visual elements in performative arts: decoration, stage design, scenic design, and scenography, with scenography being the fourth, most elaborated or creative discipline. 
Understanding scenography itself as a multimodal discipline as well as in terms of a blend of several modes, we can explain, for example, meaning construction in the first scene of Otello. As one mode, the meaning '(fighting the) sea-storm' is co-created by the music, which often relies on sound analogies of restless water elements, the sea, rain, etc.; by the singing of the libretto (e.g., 'sail' locating the storm at sea, choral invocation of divine protection, and so on); by the acting, which itself is also multimodal (e.g., frightened glances and praying gestures of the choir); as well as often also by light design, which can create light analogies or renderings of lightning. The modes react to each other. They complement each other, contrast each other, and they can be seen as being 'in dialogue'. For example, the lightning depicted in the light design can respond to the sound mode (sound analogies of thunder, and the action of the water elements expressed, for example, by percussion and string instruments).

An analysis can be performed in the following steps:

(1) The first step is applying Conceptual Metaphor Theory (CMT), introduced by George Lakoff and Mark Johnson in their book Metaphors We Live By (1980), a theory that was further developed more or less in accordance with the original concepts by other authors (e.g., by Mark Turner, Raymond W. Gibbs, Zoltán Kövecses, and others).

(2) The next step is tracking the modes that interplay in a stage design and lead to sense-generation, facilitated by access to conceptual metaphors. Multimodal Metaphor Theory was developed by Charles Forceville in cooperation with Eduardo Urios-Aparisi (2009) and also recently introduced into (cognitive) theatre studies, e.g., by Barbara Dancygier (2016).

(3) And finally, via Conceptual Blending Theory I would like to explain how the visual material as part of the scenography acts as one 'input space' which may affect meaning, even the meaning of the whole production. While I understand scenography as a multimodal component of a multimodal theatrical production, I emphasise a different distribution of the modes in operatic scenography in which the audial (sound and music) mode interplays with the visual mode in the process of meaning creation.

\section{Conceptual blending theory as an analytical tool for operatic performance analysis}

Introduced by Mark Turner and Gilles Fauconnier in 2002 in the book The Way We Think: Conceptual Blending and the Mind's Hidden Complexities, Conceptual Integration/ Blending Theory has recently come to be applied to theatre studies, e.g., in the application by Amy Cook (2010) of conceptual blending in the analysis of Shakespearean productions.

Conceptual blending, which I use as a primary analytical tool in this article, is understand as a fundamental cognitive operation. Based on Fauconnier's theory of mental 
spaces, conceptual blending can be defined as a process in which two or more input spaces are integrated to create a completely new space (a blended space or blend). A blend is based on structures and selected information taken from separate mental spaces connected together within the new blend/mental space. The mental spaces are 'constructs distinct from linguistic structures but built up in any discourse according to guidelines provided by the linguistic expressions' (FAUCONNIER 1994: 16). Blends are 'constructions of meaning based on projection of information from two or more input spaces to a blended space, such that the blended meaning contains information and structure from more than one space' (COOK 2010: 11).

I use this theory to explain theatrical event/performance on different levels: from the act of creating the character by the actor and the subsequent understanding of the actor's performance as the character's actions, through making a space in which the story takes place, to the explanation of how the meaning of the performance is made. In understanding the theatre as a multimodal phenomenon I also interpret blending as a core operation of the theatre working on different levels, especially in creating the metaphor(s) in highly symbolic productions.

Blending is understood as a core mental operation in (re)creating theatrical performance: ${ }^{8}$ the blends are based on different materials (input spaces; modes) which co-create the production. For example, in Otello we blend the actor, his decorum, physiognomy, costume as well as the lines he speaks with the story and components of performance (scenography, music, direction, etc.) to understand the character of Otello. ${ }^{9}$ As Bruce McConachie (2008) puts it, we often blend more than that. For instance, some elements of the actor's personal life, including their previous roles, enter the blend. We even compare a performance with earlier performances of other (usually 'star') actors. For example, Benedict Cumberbatch's Hamlet (2015) is compared to Laurence Olivier's (1948) or Kenneth Branagh's (1996) performance of the part. Similarly, any actor's/singer's performance of Otello is likely to be compared to Mario Del Monaco's (1950) or Plácido Domingo's (1979 debut as Otello) performances. ${ }^{10}$ This kind of blend is usually perceived by experienced spectators unconsciously without any special effort.

The complexity of blends depends on different input spaces activated by various modes. This cognitive operation usually passes unnoticed by a spectator. For example,

8 The theory is often criticised for subjectivity as connected to shifting the discourse towards cognitive processes. In my opinion, the reliability of the analytical tool offered by the blending theory can be supported by its potential to 'offer a unified explanation of both individual interpretation as well as interpretations that are shared by a group, community or culture', as Peter Stockwell puts it in his explanation of the cognitive poetics approach (STOCKWELL 2020: 6).

9 For a discussion on conceptual blending in theatrical performance analysis focused on particular topics, see e.g., John Lutterbie's work on acting (2011) and Natália Pikli's forthcoming work that discusses the actors'/audience's conceptual blending in the Hecuba scene in Hamlet.

10 Interestingly, most of the examples which the performances are compared to are captured by media other than theatre, such as cinematography. In the case of opera, the 'unrecorded example' places much higher demands on singers in live theatrical performances - not allowing a correction or refinement of the performance of the part. 
Verdi's Otello begins with the scene of a sea storm. In the staging history of this opera, different directors conceived the scene in a variety of staging ways. Yet, as I see it, the dominating input space is created by the music and by the singing of the libretto, while the visual mode serves as a conceptual target. The scene can be understood as a 'typical' example of sonic analogues the music can create via its 'grammar'. This idea has been introduced quite recently into cognitive musicologist theory by Lawrence M. Zbikowski (2017). In applying Zbikowski's theory, we can see Verdi's music (including sung text) as able to produce sonic analogues to the concept of a sea storm. Zbikowski, following Lawrence Barsalou's perceptual symbol systems theory (BARSALOU 1999), claims that 'mapping [...] from some natural phenomenon to music' is more typical than 'mapping from music to some natural phenomenon'11 (ZBIKOWSKI 2017: 36). This means that Verdi was able to create a complex scene, an audial mode of scenography, the meaning of which can be easily interpreted, especially when it is supported by the direction and (visual mode of) scenography. In this multimodal theatrical scene, the music and scenography 'connect' their faculty of analogy ${ }^{12}$ to create meaning without being dependent on or mediated by language.

My analysis of the productions discussed in this article is based on my personal experience of the performance as a spectator (Macbeth 2015) as well as on archive materials including video recordings of performances (Macbeth 2004, Otello 1991/2009) and critical reviews.

\section{Heavy and dangerous stones (Otello, Macbeth)}

On 15 November 1991, the Prague State Opera ${ }^{13}$ premiered a new production of Otello directed by Swiss director Dominik Neuner (b. 1948). The stage set was designed by Vladimír Nývlt (1927-1995) and costumes by Josef Jelínek (b. 1949). ${ }^{14}$ In 2009, the 1991 Prague production was reconstructed almost in full by Czech director Lubor Cukr (b. 1974), with only minor changes.

The 1991/2009 Otello directing-scenographic concept is rather minimalistic. The stage is almost empty at all times during the performance. Only a few stones are placed here and there, mostly together in a group. Abstract images, or rather hints of shapes reminiscent of the shapes of clouds or of sea waves, are projected onto the backdrop in the first scenes of the first act. During most of the performance, various spectral colours are projected on the backdrop screen. The colours are sometimes rich (blue, red, or grey), sometimes dim, and they vary in intensity according to developments

\section{All italics in these citations are in the original.}

12 Zbikowski (2017: 30) understands analogy as a 'key factor in human creativity'.

13 Since 2012 the Prague State Opera has been a part of the National Theatre in Prague.

14 At that time, Jelínek already had experience with costume design for operatic Shakespeare. He designed costumes for both previous productions of Verdi's Shakespearean operas in the NT in Brno in the second half of the 1980s - Macbeth (1987) and Otello (1989). The scenography for both productions in Brno was created by Ladislav Vychodil (1920-2005), another outstanding Czechoslovak scenographer. 
of the situation. The costumes have a simple cut, only remotely resembling the Elizabethan style, with no ornaments. Otello and Desdemona wear white costumes. Later, Otello wears a dark sleeveless coat, while Desdemona remains white, with only her scarf changing during the performance. A few props of a simple shape (e.g., crown, sword, wine cups) are used to depict the dramatic action and to anchor the situation. During the performance, a tip of a presumably huge stone, a sharp piece of rock, is hanging down from the ceiling as 'ready to grow' or to fall down.

The stones on the stage floor and the changes of their positions are a leading principle of the directing-scenographic concept. During the performance, the position of stones changes. In the first act, in the rear left of the stage we can see a group of round stones, including one larger stone. In the front of the stage on the right is a circle of stones within which Otello and Desdemona sing their love duet at the end of the first act. At the end of the duet, Otello and Desdemona are lying down on the 'bed' (a rectangular shape on the floor delineated by spotlight) on the front left. In that moment, on the front right, only two of the stones, initially placed in the circle made of several stones, emphasised by another spotlight, remain visible. The huge rock hangs from the ceiling and points its peak down to the characters. In the second act, the stones are grouped in the centre of the stage below the hanging rock. Standing on the biggest stone, Jago sings his 'Credo'. While singing the words 'Credo con fermo cuor' ${ }^{15}$ he moves behind the stones, he makes a sign of a cross and appears to copy with his hands the shape of the stone lying before him as he is pronouncing the word 'cuor' ('heart'). He climbs the stone with small stones in each of his hands and straightens up in accordance with the rising dynamics of the music (see Fig. 1). After the peak of his 'aria' in the pause after the 'dal germe della culla'16 - just a few bars before the words 'E poi? e poi? La Morte e'il Nulla'17 - he drops the stones. In the scene with the handkerchief, Otello picks up one of these two stones to put it to his forehead (instead of Desdemona's handkerchief thrown to the ground a few seconds earlier). A few moments later, Otello kneels down and puts it on the ground in front of the stage. The second one of 'Jago's' stones is picked up by Otello at the end of the second act in the duet with Jago when he (with Jago's support) swears revenge.

The third act begins with Otello sitting on the stone in the middle of the stage. There are nine round stones on the stage placed in three rows in almost perfect symmetry in the shape of a square (three rows of three stones). During this act, the characters move among the stones, which can be seen to embody the obstacles between the characters. The main characters act and struggle with their fate as if they were (literally) amongst the millstones. In the fourth act, the stones are gone. Only a rectangular piece of cloth lies in the middle of the stage straight below the huge hanging rock. The cloth represents a bed. The shape of Desdemona's (and Otello's) bed has already been depicted by the light (in a rectangular shape) in several former scenes in different parts of the

15 'I believe with a strong heart. / I strongly believe' (The first variant of translation is mine, the second is by Burton D. Fischer (2001: 60)).

16 'from the germ of the cradle' (FISCHER 2001: 60).

17 'And then? And then? Death is nothingness' (FISCHER 2001: 60). 


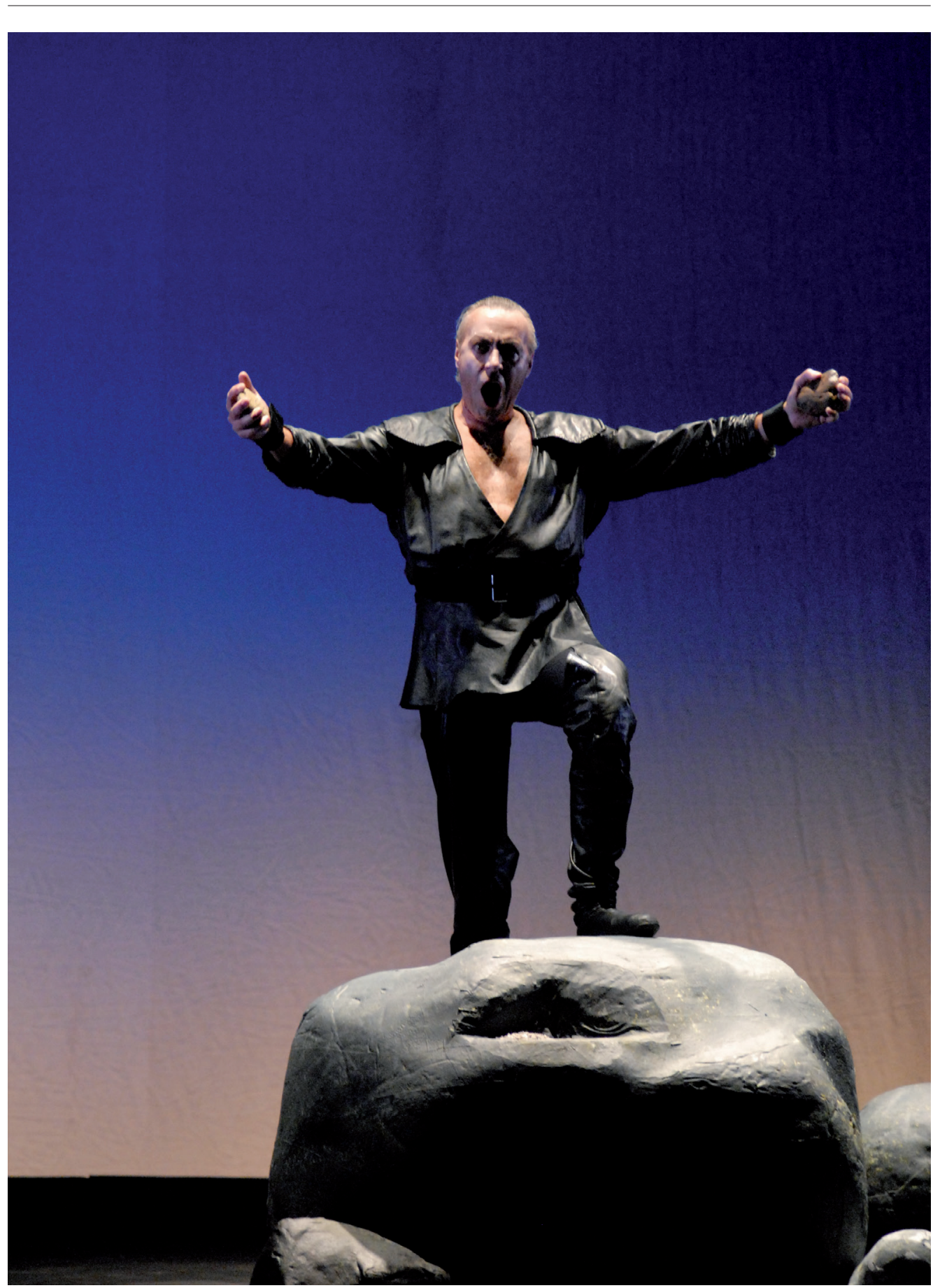

Fig. 1: Otello 2009. Richard Haan (Jago). Photo: Karel Kouba. NT Prague Archives, State Opera Prague collection. 
stage. Now the bed is 'materialised' by the cloth and placed straight under the rock pointing down. At the very end of the story, the rock slowly descends, stopping approximately one meter above the floor above Otello crying over the dead Desdemona, at which point the lights go out.

The directing-scenography concept uses the stones to conceptualise the story via several metaphors. For example, via stage actions supported by the visual mode of scenography these metaphors could be associated with this part of the direction-scenography concept: JAGO'S HEART IS STONE, EVIL IS STONE, DOUBTS ARE STONES, and EMOTIONS ARE STONES (in which heaviness, among other aspects, is especially emphasised). ${ }^{18}$ Towards the end of the performance every piece of stone stands 'isolated' from the others. In most of the concluding scenes, the circles of light made by the spotlights emphasise the 'lonely' position of every single stone. Moreover, an additional tendency in the stone-positioning can be traced. In the first scenes, the stones are placed asymmetrically, grouped together randomly. This aspect, however, does not acquire significance until the moment they appear in an almost perfect symmetrical arrangement in the third act. From the beginning of the third act, the scenography anticipates the scene when Otello humiliates Desdemona in the presence of Lodovico, the ambassador of the Venetian Republic. In this scene the stones are set wide apart, and their distribution can be interpreted as an 'attempted' symmetry which at the same time represents total separation. At this critical moment, no single stone touches any other stone, as no character approaches nor is in connection with another character. This is the very last formation of the stones on the stage in the performance. The symmetry can be understood as a manifestation of the disintegration which can be derived from the culturally based metaphor THE SOLIDITY OF A STONE IS THE INTEGRITY OF SELF. It is Jago who aims at symmetry in this sense and in this story. The scenography creates an analogue by the asymmetrical grouping and re-grouping of the stones standing for the changing situations of the main characters and eventual symmetry (Fig. 2), i.e., the loss of integrity. Further, it is Jago who interacts with the stones more often and more consciously, i.e., he appears to play with them. From this perspective, the stones and their changing formations can be, according to Jago's actions, interpreted as figures on a game board.

In terms of conceptual blending theory, we can interpret several interconnected meanings. Overall, some input spaces of the scenographic blend are shaped by the operatic work itself - by the libretto (the text sung on the stage) and the musical material of the score (coming from the orchestra pit during the performance). In a performance, this is also inseparably connected to the direction. So in speaking about the 'visual mode' or 'visual material' of input space, I treat it in this complex way. The visual mode of scenography changes from production to production. In terms of conceptual blending theory, the visual mode creates a separate input space in which visual information activates bits of relevant information from memory, which facilitates and allows interpretation. For example, the 'stone' is a stimulus that - depending on other elements of context - draws various elements from our

18 I use the convention of the conceptual metaphor theory of writing the conceptual metaphors in small capital letters. 


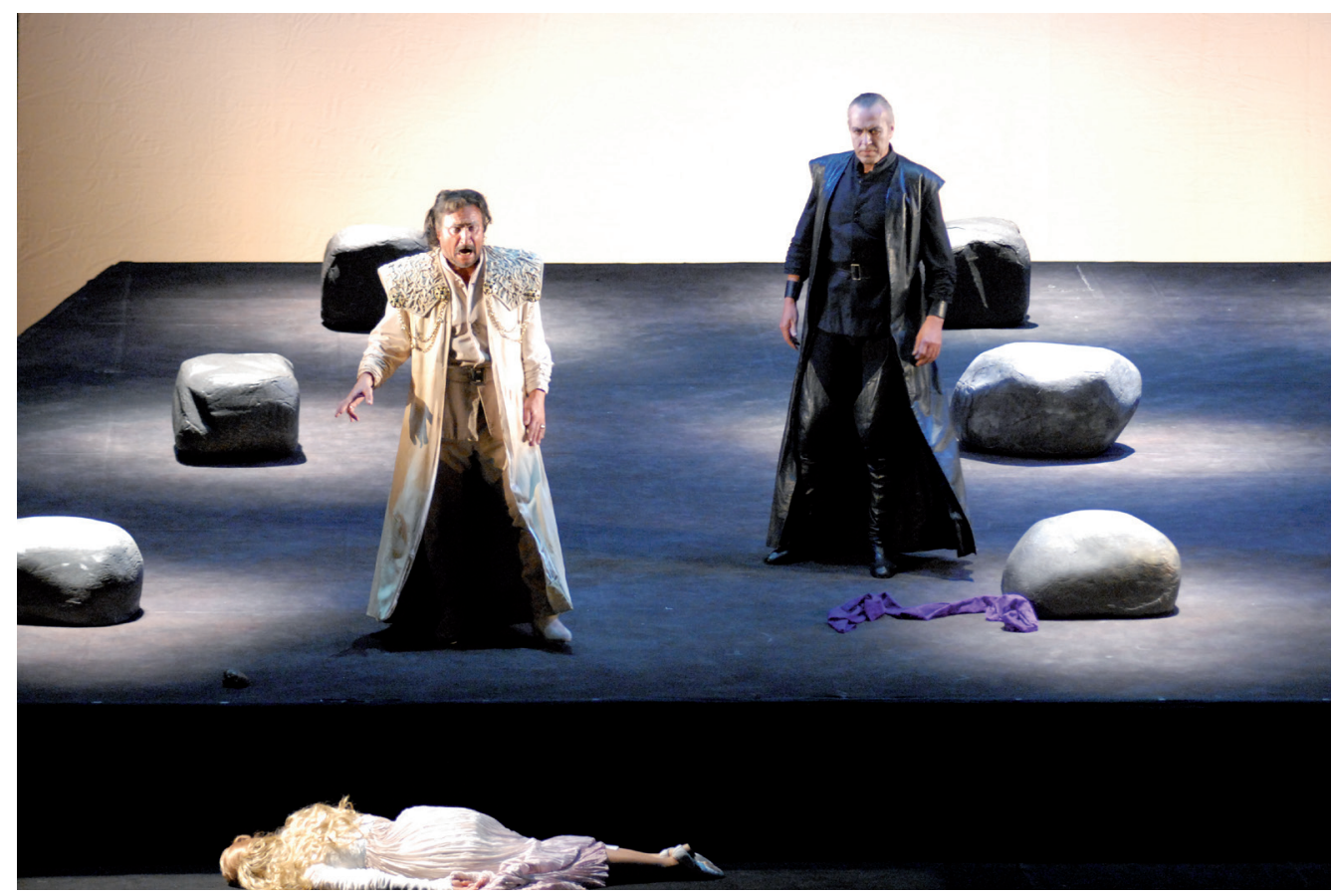

Fig. 2: Otello 2009. Sergej Ljadov (Otello), Richard Haan (Jago), and Marina Vyskvorkina (Desdemona). Photo: Karel Kouba. NT Prague Archives, State Opera Prague collection.

memory: e.g., coldness. While scenography for Otello during the Communist era approximately up to the 1960 s usually created the visual input space as an Elizabethan Cyprus, in later productions the visual input space became more and more abstract, depicted less specifically. The visual input space of the 1991/2009 production includes the motion of the stones and the changes in their placement on the stage. This input space blends with other input spaces, such as Otello's changing mind as represented by his actions. In a generic space we can see the change from a cohesive whole to a gradually divided, fragmented one. The destruction of the integrity of the character's mind is also visually represented through scenography supported by other modes which shape the meaning of the production. The opera in this case does not only tell the historical story (a story that may once have happened in Cyprus during Elizabethan times) but places the story into an abstract space organised almost by a single material (stone) and by focusing on the motion of stones and changes in closeness or integrity. Similarly, stone(s) as an input space can also be connected and mapped to the input space of Otello's and Desdemona's relationship - the input space that can also be found in the opera work itself. In the blended space there is - again - a loss of integrity, a separation. There is a metaphoric meaning involved: the relationship of the couple is falling apart. Figure 3 shows how this projection happens. 


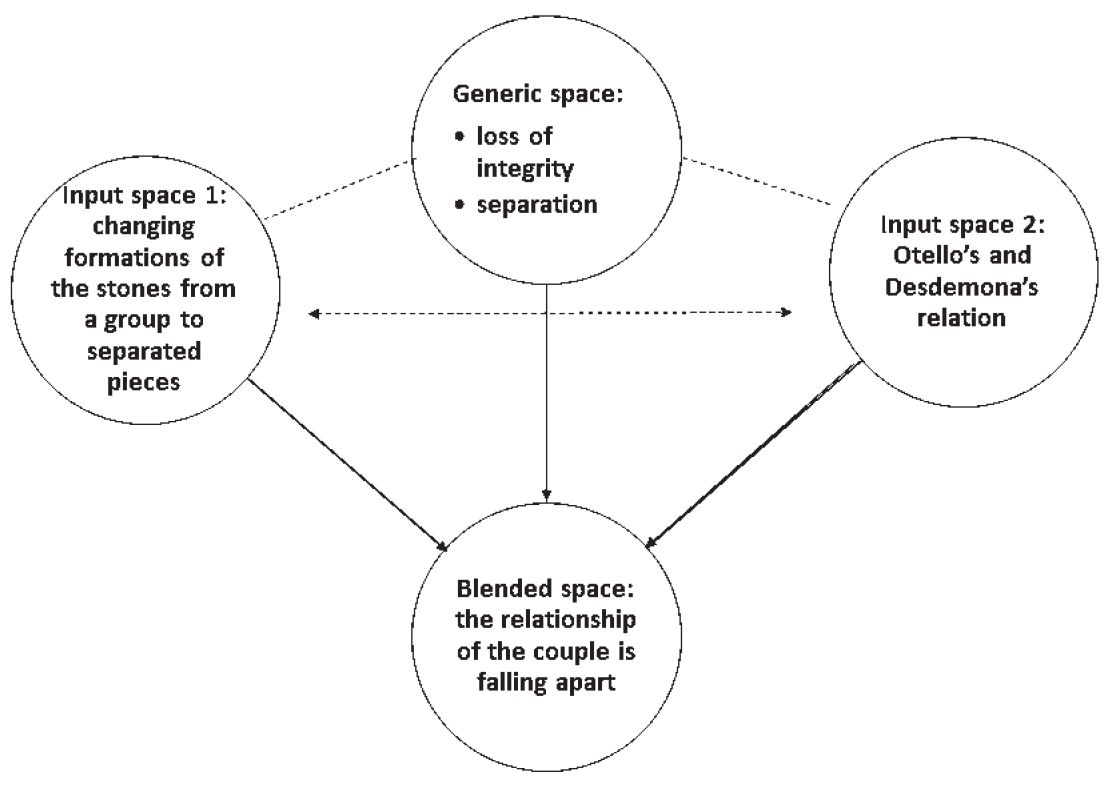

Fig. 3: The relationship of the couple is falling apart.

To interpret Jago's actions through a symbolic use of stones on stage I will focus on two of Jago's actions performed during his Credo monologue - his climbing and standing (triumphantly) on the group of stones and his playing with the small stones (holding them and dropping them on the ground). Jago is mastering the stone-element, separating pieces from the group in a playful and intentionally crude way. Via mapping the stones' input space to Jago's actions' input space we can identify the changes in generic space, but also changes caused by a particular agent (Jago), which affect somebody else (Otello, Desdemona, etc.). We can also identify the features of a game, since Jago's actions create a part of his game and since the organisation of the stones changes into a symmetric pattern resembling the pieces on a game board. Also, our experience with the quality of stone itself, e.g., hardness, can be projected onto Jago's deeds and his character. Meanings such as 'Jago's hard/cruel deeds/character leads to the destruction of Otello's mind and Otello's and Desdemona's relationship' can be accessed through the visual mode of scenography.

Since the projections from the input spaces are selective, what further cognitive mappings within the scenography-direction concept are possible? The options of playing with blends are perhaps infinite. The lonely stones in the scene with Lodovico (Fig. 4) can be interpreted as a metaphorical expression of loneliness, since the destruction of the relationship is expressed by the replacement of the stones. In this situation, the stones are arranged symmetrically and lit intensely by the spotlights. This scene focuses on Otello's public humiliation of Desdemona. During the whole third act, each stone lies separately, apart from each other. The formation resembles a stadium or the result 


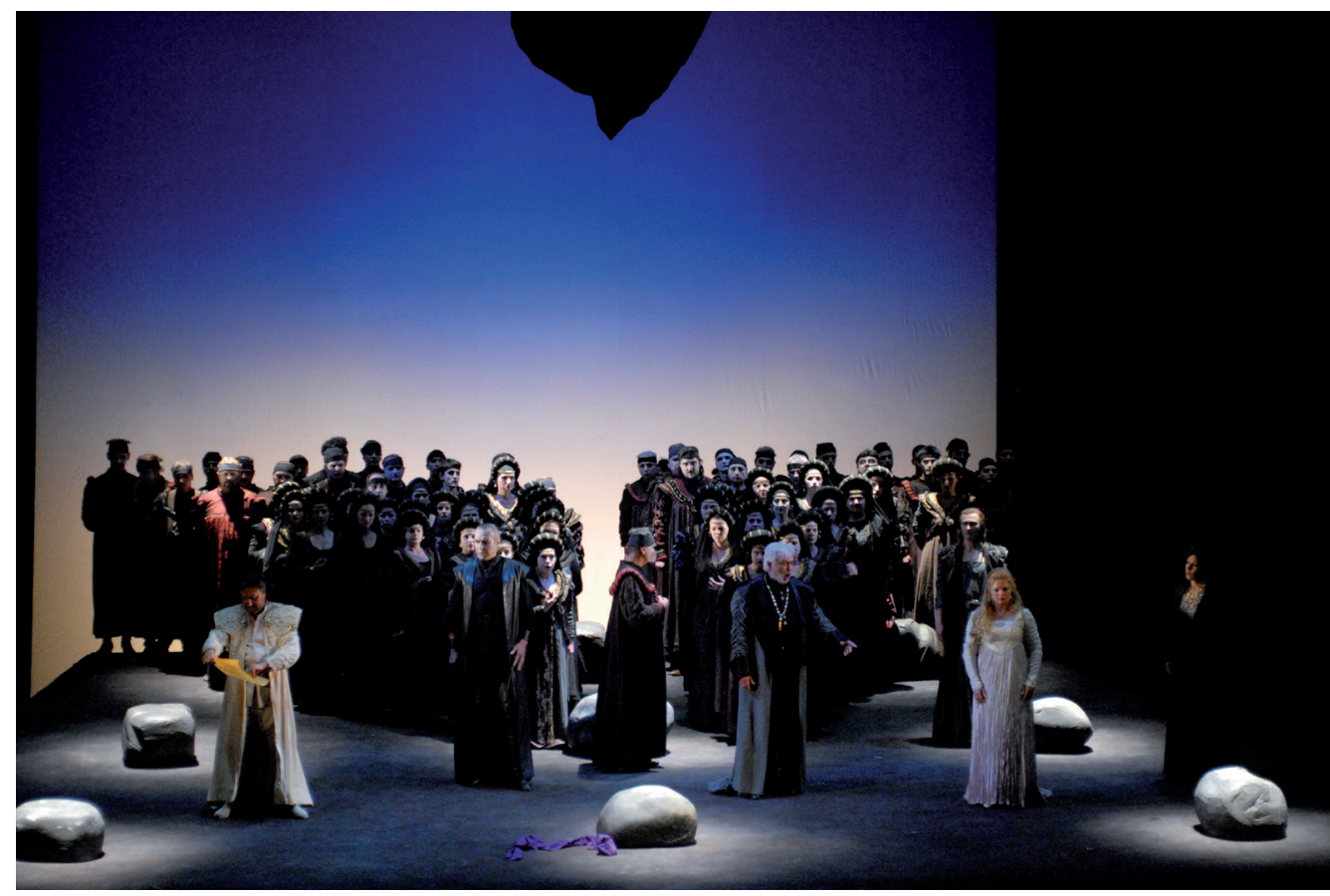

Fig. 4: Otello 2009. Sergej Ljadov (Otello), Richard Haan (Jago), Milan Bürger (Lodovico), Marina Vyskvorkina (Desdemona), Jiři Hruška (Roderigo), and Jana Levicová (Emilia). Photo: Karel Kouba. NT Prague Archives, State Opera Prague collection.

of a game. As the action of a singer is usually staged, i.e., the actress falls exhausted down on her knees, eventually crying; this represents Desdemona's fall literally, but also, in a more complex blend, a fall in a metaphorical sense.

The blending can also provide another meaning. We can metaphorically map Desdemona's loneliness onto the hardness of the stones controlled by Jago (which can be associated further, e.g., with the heartlessness of Jago, etc.). This may also stimulate a blend in which Desdemona resembles a stray boulder. It can also be connected to the meaning already raised in Otello's mind or in Otello and Desdemona's relationship: the arrangement and then disarrangement of the stones can express the loss of integrity, now a completed process; or a loss of (emotional) connection between Desdemona and Otello. Another example is worth mentioning: in the 2019 Royal Opera House production director Keith Warner (born 1956) and scenographer of Slovak origin Boris Kudlička (born 1972), who had studied stage design in Bratislava and Warsaw, expressed the process of the weakening of the connection between the couple via a gradual decomposition of the floor, with parts of the stage floor gradually removed. The front and back parts of the stage were divided, with only a few narrow bridges above the 'abyss' (in a blend imagined in/under the floor) left by the end of the tragedy. In any case, the space and the changes of the space refer to elements other than space, i.e., to the story development, to the inner state of the characters (emotional processes), etc. 


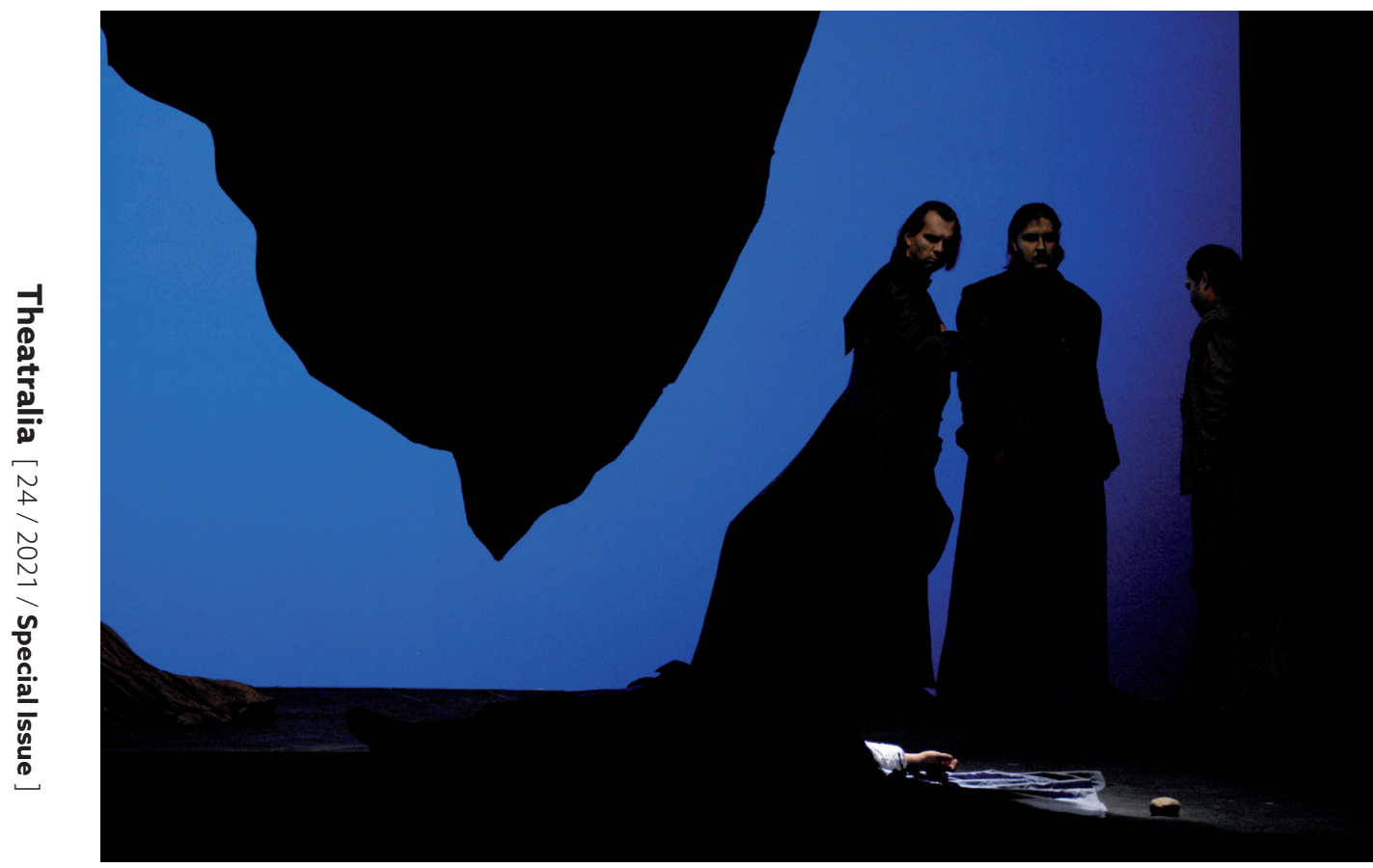

Fig. 5: Otello 2009. Ivo Hrachovec (Montano), Miloš Horák (Lodovico), and Václav Sibera (Cassio). Photo: Karel Kouba. NT Prague Archives, State Opera Prague collection.

Apart from the smaller rocks scattered and moved about on the stage, the audience also sees another lump of rock hanging from above (see Fig. 5) in an effect which raises a new question: how does this huge stone hanging down from the ceiling ${ }^{19}$ shift the meaning of the already mentioned blends? The rock hanging from the ceiling shifts the 'play with blends' (SERESS 2012) ${ }^{20}$ even further. From the point of view of setting the plot which is prescribed in the libretto (and Shakespeare's play), at this point, the scenography forgoes any direct association at all, with the only 'concrete' meaning a 'piece of rock'. So in this moment our faculty of blending is called to operate again. The stone hangs above the stage during the whole performance and is lowered only at the very end. The object hovers over the stage and obviously it should be interpreted metaphorically - as something huge and heavy hanging above the story developing under it, something that is about to fall and could destroy everything at any moment. We

19 Another layer of meaning might include the fact that everyone involved, including the audience, is very well aware that a stage piece of rock is made of a light material. Thus, one of the first blends we have to perform is to blend the light material in the shape of a rock with the attributes of rock, including, e.g., heaviness, coldness, etc. These qualities are the basis for creating metaphorical blends, e.g., the motionlessness or hardness which can be further connected to a character (e.g., Otello) and interpreted as 'severity', coldness, and hardheartedness (of Iago).

20 I refer to the title of an article by Ákos Seress (2012), one of the first articles focusing on the cognitive approach in theatre studies written by an author from the Visegrad countries. 
can identify the hanging rock as one more input space (the rock is huge, heavy enough to kill or hurt a man), and the situations of the developing story as another input space. There is a life-threatening danger that remains present. An emergent structure arises as something about to fall and destroy something else, i.e., a threat, one specified in one input space (a rock) and in another space specified (non-linguistically) as a hidden, waiting danger. The rock expresses a danger 'growing' from somewhere above, falling down on the characters. The hugeness, heaviness, and even sharpness can be seen as significant from the point of view of the direction-scenography conception.

The fact that the stones are almost the only material in the visual mode of scenography is worth special attention. What is the relation of the stones on the ground to the one hanging from the ceiling? Visually, the latter differs in several aspects: it is huge, it has a sharp edge/tip pointing down, it does not move (until the very end of the performance), and due to its position and dim lighting it might not be noticed by a spectator, at least not at first. Can the threat of the same material in a different shape which remains unnoticed be seen as more dangerous to the characters? Perhaps the threat concentrated on the dangerous rock hanging above the human beings could be interpreted as amplification of the meaning. More importantly, the stones on the stage often interact with the actors, both directly in their actions as well as indirectly within spectators' minds creating various meanings. The huge rock frames the performance as a whole and is not perceived by the characters, i.e., the actors' attention is not intentionally (by the direction) focused on it. In meaning construction, it works on another, meta-level. Moreover, for those spectators who are familiar with the staging tradition of Otello, the rock in a picture frame view can be interpreted as a substitution for the winged Lion of Venice, as well as for Otello. The Lion of Venice has been used as a symbol visible to the audience throughout an entire performance, as for example in the 1967 production in the State (today National) Theatre in Brno, where the Lion was placed upstage at the center of the proscenium arch. The rock - huge, heavy, sharp and, most importantly, hidden - forms one input space. The developing story, Jago's evil deeds, on the stage is another input space. In the generic space, they share a quality to endanger and to end human life (Fig. 6). Only the spectator's attention is called to be focused on it and on its meaning, i.e., to frame the previous meanings and blend them further to the very end. The visual mode of scenography creates a focal point for the 1991/2009 production and can be understood as a leading factor in meaning construction..$^{21}$

Interestingly, in the 2015 Prague National Theatre production of Verdi's Macbeth the huge 'rock' hanging above the characters was used again. Although the operatic Macbeth has a more complex net of mental spaces - at least two historical times are

21 To compare the findings of the analysis, some comments of the reviewers are worth mentioning. In the case of the 1991/2009 production of Otello, Věra Benešová (1991), for example, interpreted the stones and their formations in connection to the inner states of the characters; Jago's interplay with the stones was emphasised e.g., by Petr Špergl (1991). Vlasta Reittererová (2009) in her commentary on the performance of the revised version mentioned how the scenography supported the relationships among the characters; Dana Šimková (2010) described how the number of the stones changed throughout the performance and commented on their impact on the viewer's imagination; and Radmila Hrdinová (2009) questioned the meaning of the stones. 


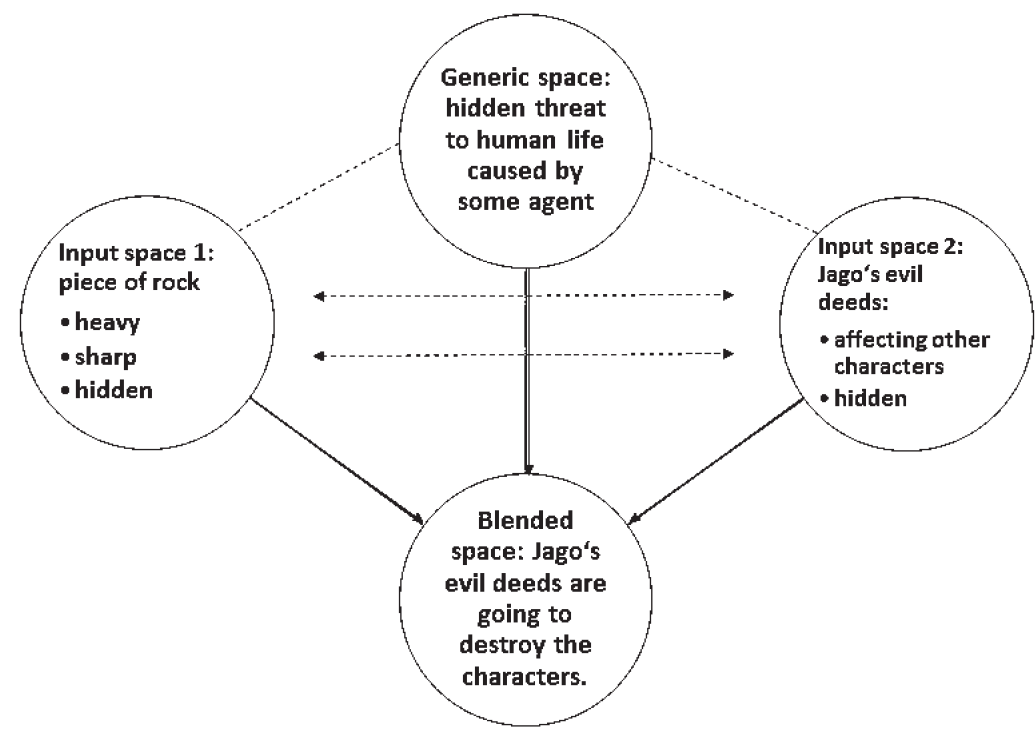

Fig. 6: Jago's evil deeds are going to destroy the characters.

involved in the plot (Macbeth's present and future) - and the visual mode of the production scenography was more complex than the above discussed Otello, I would like to briefly focus on the process of meaning creation in the direction-scenography conception of this production of Macbeth. In this case the rock was not depicted in the directing-scenography concept by Slovak director Martin Čičvák (b. 1975) and Austrian scenographer Hans Hoffer as a 'latent' threat as in the production of Otello, where it was lowered only once at the very end of the performance. This part of the Macbeth 2015 scenography was not 'only' hanging from the ceiling for most of the time during the performance, but it was gradually lowered as the performance progressed. Taking it as one input space and Macbeth's actions as another, with 'rising of something bad/dangerous', the emergent structure clearly directs the blend. Macbeth's deeds, his rising evil, are - via the falling rock metaphor for these evil deeds - falling, rising from above, onto him. In the last act, in the scene of Macbeth's defeat, the actor's concurrent actions (his acting at the moment) are projected onto the surface of the 'rock'. At this moment, the rock is quite close (approx. 1.5-2 metres) to the stage floor, with a substantial part of the picture frame view filled with its mass. The rock descends gradually until it reaches its final position, with the meaning emerging instantly and clearly: Macbeth is now about to be destroyed by the 'heaviness' of his own deeds (Fig. 7). In comparison to the Otello production, the rock is not shown only to the spectators to 'create' the meaning, but as actor-Macbeth shows in his action at this moment, also the character is to comprehend the meaning of the stone metaphor. The character is suddenly confronted directly with the rock falling 


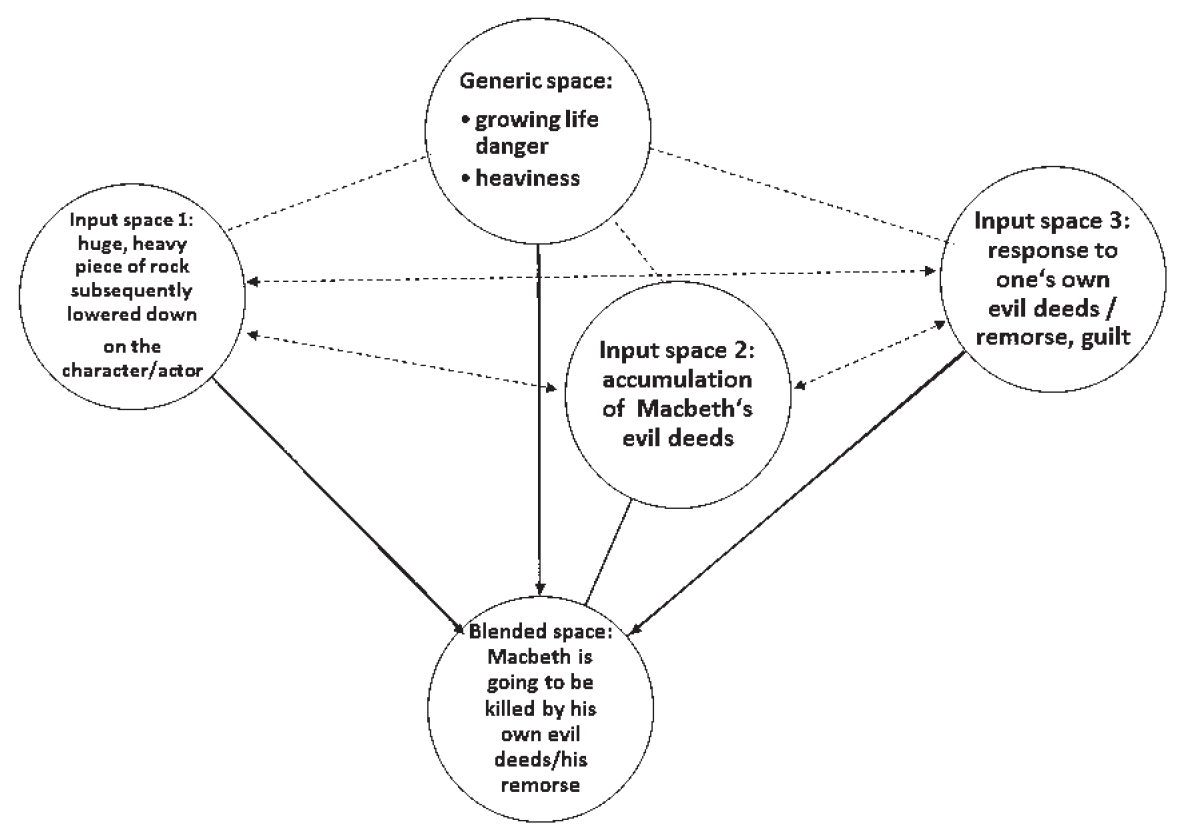

Fig. 7: Heaviness of Macbeth's own evil deeds is going to destroy him.

on him. He is pushed - instantly - to understand the cause of his end, as if the 'Great Birnam wood' came against him.

Again, the spectator who attended the Otello 1991/2009 production might integrate the mental spaces further by comparing the meanings shaped by the scenography based on the stone input spaces of both productions.

\section{Conclusion}

As can be seen from the two described productions, the visual mode of Czech scenography of operatic Shakespeare after 1989 tended towards using abstract elements, i.e., usually specific materials in non-specific or rather general shapes. Although I focused only on the example of one material used as the basis for the visual mode of contemporary operatic scenography, the tendency might be traced in other productions, e.g., in Jaroslav Malina's scenography for Macbeth 2004 in Ostrava based on different shapes of red shaped by the light design as projected onto a canvas backdrop. ${ }^{22}$ Or, for instance, rather unspecific elements such as a large rectangular platform covered by the cloths of different colours (black, white), the meaning of which was articulated in different scenes by the direction in acting (Otello, 2009, NT Brno). The dominant 
quadrangular platform covered by black cloth forms one input space which is blended further with the input space of the actions of Lady Macbeth (and her interaction with Macbeth), such as a woman/Lady Macbeth manipulating a man via her sexuality. The bed is a place (a castle) from where Lady Macbeth rules both her husband through his actions and the kingdom. In this case, the scenography, its visual mode, together with the direction shifts or emphasises a specific meaning the work is able to convey. The direction shapes the scenography, its visual mode, with the meaning of the scenes which follow derived from this blend. Once Lady Macbeth is characterised as a 'dominatrix' or even a courtesan (according to the costume and acting, her characterisation balances on the edge of the meaning of sexy wife and a brothel girl) ruling Macbeth, what does this communicate regarding the nature of a kingdom? And when Lady Macbeth becomes the queen, the blend could run further as a new meaning emerges: a queenbrothel keeper, and so forth.

In this article I have discussed the procedure of a multimodal analysis of scenography based on the blending theory approach. By abstracting the scenography, the significance of the production, as noted, of the 1991/2009 Otello of the Prague State Opera, focuses on basic, more universal concepts such as the destruction of a relationship, integrity of the self, as well as imperceptible influencing and manipulation, among other topoi. In the scenography of earlier Shakespearean opera productions (approximately up to the late 1960s), these concepts were also accessible, but only through the layer of historical (e.g., Elizabethan era) space created mostly by the visual mode of scenography.

I have provided only a handful of examples, but I suggest that they can be considered as representations of overall tendencies which are traceable in the staging style of post-1989 Czech operatic productions. ${ }^{23}$ The visual mode of the scenography starts (and partially continues) using more abstract elements. These elements, however, are able to concretise complex abstract ideas within the works of art as well as focus audience attention on the intended meaning the artists (staging team) seek to express and convey. Taken as one of the input mental spaces we blend, the visual mode of scenography shapes the meaning of a production into clear, usually generally comprehensible concepts and ideas. During the Communist regime, the metaphoric potential of scenography could not fully develop, since some topics were too sensitive from a political point of view. Nevertheless, the techniques and approaches the scenographers developed during the Communist era (for example action scenography) can be taken as competencies which, although in altered form, are returning and are applied even today, long after 1989 .

23 The methodology applied could help trace similar tendencies in other productions of the period which could become the object of future study. 


\section{Bibliography}

BARSALOU, Lawrence W. 1999. Perceptual Symbol Systems. Behavioral and Brain Sciences 22 (August 1999): 4: 577-660.

BENEŠOVÁ, Věra. 1991. Otello ve Smetanově divadle [Otello in Smetana's Theatre]. Zemědělské noviny (27. 10. 1991).

COOK, Amy. 2010. Shakespearean Neuroplay: Reinvigorating the Study of Dramatic Text and Performance through Cognitive Science. New York: Palgrave Macmillan, 2010.

DANCYGIER, Barbara. 2016. Multimodality and Theatre: Material Objects, Bodies and Language. In Rhonda Blair and Amy Cook (eds.). Theatre, Performance and Cognition: Languages, Bodies and Ecologies. New York: Bloomsbury, 2016: 21-39.

FAUCONNIER, Gilles. 1994. Mental Spaces: Aspects of Meaning Construction in Natural Language. Cambridge: Cambridge University Press, 1994.

FISCHER, Burton D. 2001. Verdi's Otello. Miami: Opera Journeys Publishing/Coral Gables, 2001. FORCEVILLE, Charles and Eduardo URIOS-APARISI (eds.). 2009. Multimodal Metaphor. Berlin and New York: Mouton de Gruyter, 2009.

FORCEVILLE, Charles. 2009. Non-verbal and Multimodal Metaphor in a Cognitivist Framework: Agendas for Research. In Charles Forceville and Eduardo Urios-Aparisi (eds.). Multimodal Metaphor. Berlin and New York: Mouton de Gruyter, 2009: 19-40.

HAVLÍČKOVÁ KYSOVÁ, Šárka. 2016. Stage Metaphors in Verdi’s Otello: Miloš Wasserbauer's production in State Theatre in Brno (1967) in the Context of the Opera Staging Tradition. Theatralia 19 (2016): 2: 29-58.

HAVLÍČKOVÁ KYSOVÁ, Šárka. 2021. Audio-visual Metaphors in Operatic Shakespeare: Verdi's Macbeth and Otello in Czech Theatres. In Christopher Wilson and Mervyn Cooke (eds.). Oxford Handbook of Shakespeare and Music. Oxford: Oxford University Press, 2021, forthcoming. HRDINOVÁ, Radmila. 2009. Zůstala forma, vytratil se obsah [Only the Form Remains, The Content is Lost]. Právo (30. 5. 2009): 24.

JINDRA, Vladimír. 1983. Specificity of Scenography. Prague: Theatre Institute, 1983.

LAKOFF, George and Mark JOHNSON. 1980. Metaphors We Live By. Chicago and London: University of Chicago Press, 1980.

LUTTERBIE, John. 2011. Towards a General Theory of Acting. Cognitive Science and Performance. New York: Palgrave Macmillan, 2011.

MCCONACHIE, Bruce. 2008. Engaging Audiences. A Cognitive Approach to Spectating in the Theatre. New York: Palgrave Macmillan, 2008.

PIKLI, Natália. 2020. 'Mobled Queens' and 'Dunghill Idiots': The Trojan War as Metatheatre and Parody. 37th International Shakespeare Conference 'Shakespeare and War', 22-27 July 2020, Stratford-upon-Avon.

REITTEREROVÁ, Vlasta. 2009. Láska, moc a žárlivost [Love, Power, and Jealousy]. Hudebni rozhledy (1. 7. 2009): 37. 
SERESS, Ákos. 2012. Playing with Blends. Theatre Studies and Cognitive Science. Apertúra 2012. [accessed on 31.05.2020]. Available online at https://www.apertura.hu/2012/osz/seress-playing-with-blends-theatre-studies-and-cognitive-science/.

STOCKWELL, Peter. 2020. Cognitive Poetics. An Introduction. Oxon: Routledge, 2020.

ŠIMKOVÁ, Dana. 2010. Otello - v hlavní roli Jago a Desdemona [Otello - Jago and Desdemona as Main Characters]. Operadream.blogspot.com (26. 8. 2010).

ŠPERGL, Petr. Kámen jako symbol zla [A Stone as a Symbol of Evil]. Český denik (22. 11. 1991).

TURNER, Mark and Gilles FAUCONNIER. 2002. The Way We Think: Conceptual Blending and the Mind's Hidden Complexities. New York: Basic Books, 2002.

VERDI, Giuseppe. Otello 2009 [DVD, performance recorded 29.01.2015]. Prague: National Theatre Prague, 2015. Stored at the NT Prague Archive.

ZBIKOWSKI, Lawrence M. 2017. Foundations of Musical Grammar. New York: Oxford University Press, 2017. 


\section{Šárka Havlíčková Kysová}

Department of Theatre Studies

Masaryk University

Gorkého 57/7, 60200 Brno, Czech Republic

sarka.havlicek@mail.muni.cz

ORCID: https://orcid.org/0000-0002-1259-5991

Šárka Havlíčková Kysová, Ph.D., is an assistant professor at the Department of Theatre Studies, Masaryk University, Brno, Czech Republic. She studied Theatre Theory and History along with Czech Language and Literature at Masaryk University. In 2010 she received her Ph.D. in Theatre Theory from Masaryk University with her thesis Hastabhinaya. Hand Gestures in the Traditional Theatre Art of India. In her research and teaching she focuses on theatre theory and on the staging of opera. She focuses on the application of cognitive approaches to theatre, especially on conceptual metaphor theory, conceptual blending theory, and multimodal metaphor in the analysis of opera staging practice. 